\title{
Język muzeum, czyli o nowych sposobach odczytywania wystaw
}

\section{Language of the museum, about new ways of interpreting exhibitions}

\author{
Beata Niklewicz \\ Uniwersytet im. Adama Mickiewicza
}

\begin{abstract}
Linguistic theory which Mieke Bal presented in her text The Talking Museum, reproduced in the book Double Exposures: The Subject of Cultural Analysis, is one of the clearest signs of the New Museology. This self- critical field indicates changes in museum studies at the end of the twentieth century.
\end{abstract}

Key words: new museology, museum education, intertextuality

Streszczenie: Artykuł stanowi refleksję na temat współczesnego muzeum. Ukazuje przestrzeń wystawienniczą, z jednej strony jako przestrzeń narracji - miejsce dialogu obiektów, kuratorów i widzów, z drugiej jako narrację przestrzeni - legitymizującą dzieła i formującą ich przekaz. Najistotniejszy kontekst stanowią badania sytuujące się w obszarze nowej muzeologii, wskazujące na możliwość wprowadzenia do języka muzeum elementów interdyscyplinarnych, również z zakresu literaturoznawstwa.

Słowa kluczowe: nowa muzeologia, edukacja muzealna, intertekstualność

Muzeum to przestrzeń narracji, miejsce dialogu obiektów, kuratorów i widzów, ale - co nie mniej ważne - narracja przestrzeni. Język muzeum towarzyszy instytucji od początków jej istnienia i choć od ponad trzydziestu lat jest demaskowany, to nadal istnieją miejsca, w których rzadko się go dostrzega. Jednym z nich jest szkoła.

Stosunkowo krótka, jeśli przyrównamy ją do liczącej dwa tysiące lat tradycji kolekcjonerskiej, trwająca niewiele ponad dwa wieki historia muzeum jako instytucji zaowocowała powstaniem na początku lat 50. odrębnej dziedziny nauki. Zdefiniowana przez Georgesa Henriego Rivier'a muzeologia już trzydzieści lat później zaczęła podlegać trwającemu do dziś procesowi redefinicji, określającemu status „nowej muzeologii”. To niezwykłe zjawisko sprawiło, ze bastion przeszłości stał się areną współczesnej debaty. 


\section{Podstawy „nowej muzeologii” 1}

Sturm und Drang (okres burzy i naporu) - nie inaczej można określić to, co działo się w muzeologii przez ostatnie trzydzieści lat. W wyniku tych przemian muzeum jakby dorosło, zyskało samoświadomość i zaznaczyło swoją pozycję w obszarze humanistyki. Ta przemiana stała się jednak udziałem i radością niewielu. Dostrzegło ją wąskie grono badaczy, czytelników prasy specjalistycznej i... najmłodszych gości muzeum, dla których dziwienie się i zadawanie pytań to najbardziej naturalny sposób poznawania rzeczywistości. Niestety, pojawił się zapewne zasadny niepokój, że dla pozostałych widzów zmieniło się niewiele. Ta stagnacja ma dwa oblicza. $Z$ jednej strony chętnie wierzymy $w$ to, co widzimy, ufamy źródłom, znakom pozostawionym przez historię, każdy przedmiot ma dla nas wartość sam w sobie. To charakteryzuje jednostkowy, estetyczny odbiór sztuki. Muzeum jako takie pozostaje transparentne, to tylko zbiór oświetlonych pomieszczeń, w których umieszczono podpisane dzieła $\mathrm{w}$ jakimś stałym, z góry ustalonym porządku. Z drugiej strony - wręcz przeciwnie - miejsce, w którym oglądamy na przykład obrazy, jest dla nas wartościujące, co realizuje się w stwierdzeniu: to jest „prawdziwa sztuka” [sic!], bo inaczej nie byłoby tego w muzeum. Organizujemy zatem nobilitujące, w naszym przekonaniu, wycieczki - do instytucji chroniącej kulturę i sztukę, cieszącej się społecznym zaufaniem. W efekcie nawet jeżeli nie wiemy, czym jest sztuka, to doskonale potrafimy wskazać miejsce jej ekspozycji i tym samym legitymizacji. To muzeum! Zapominamy jednak, że nie ma tu dogmatu, ale jest za to paradygmat umysłowej naiwności usprawiedliwiany tradycją, wychowaniem, a do niedawna nawet edukacją. To właśnie temu przeciwstawia się nowa muzeologia - już od trzydziestu lat...

\section{Dlaczego muzeum jest takie ciekawe?}

Mieke Bal pytając o „nową muzeologię”, ujmuje ją w kategoriach humanistycznych. Konsekwencją tego jest wskazanie trzech obszarów, za sprawą których muzeum stanowi ważki przedmiot badań. Po pierwsze, ze względu na konieczność wykorzystania wiedzy z różnych dziedzin, między innymi historii sztuki, architektury, teorii literatury, socjologii wpisuje się w nurt rozważań interdyscyplinarnych. Po drugie - „jego istotą jest debata estetyczna" (Bal 2005, 345) o charakterze publicznym. To tu kryje się największy potencjał edukacyjny muzeum. To wszystko w efekcie a zatem po trzecie - określa społeczny, międzyludzki, podmiotowy wymiar muzeum jako instytucji. Dodatkowo w nowej muzeologii, istotny wydaje

1 Nowa muzeologia - pojęcie wprowadzone przez Petera Vergo (The New Museology, ed. Peter Vergo, London 1989), określające przemiany zachodzące w muzealnictwie pod koniec XX w. 
się wymiar antropologii krytycznej. Perspektywa ta, proponująca holistyczne spojrzenie na kulturę, możliwe jedynie za sprawą interdyscyplinarnych narzędzi, wyróżnia tę - jak podkreśla badaczka - „obecnie najbardziej samokrytyczną dziedzinę nauki" (Bal 2005, 345).

Warto pamiętać, że refleksja ta nie dotyczy jedynie muzeum sztuki. Jest tak za sprawą estetyki, która pozostaje drugorzędna wobec podstawowych celów antropologii krytycznej. W kontekście „nowej muzeologii” oznacza to możliwość przesunięcia zainteresowań z muzeów sztuki w stronę muzeów etnograficznych i historycznych. W tych właśnie rozważaniach Bal odnajduje impuls do rozwoju lingwistycznej teorii muzeum. Wychodząc od muzeum etnograficznego - jako instytucji uwikłanej politycznie - badaczka przywołuje jedną z prymarnych myśli Thomasa Seligmana. Amerykański badacz pyta retorycznie: „czy jesteśmy winni próby narzucenia naszych nowo odkrytych wartości danej kulturze poprzez zajmowanie się jej własnością kulturową?"(za: Bal 2005, 348). Zatem - na ile badanie (i badający) zmieniają przedmiot badań? A zmieniają na pewno, ponieważ każde kryterium nie tylko jest subiektywne, ale i podlega subiektywnej interpretacji. W przypadku muzeum etnograficznego to wszystko zostaje dodatkowo ujęte w nawias różnicy kulturowej i problemu własności. Innymi słowy, do kogo należy przedmiot w muzeum etnograficznym? Do tego, kto go stworzył lub posiadał, czy do tego, kto go zbadał, nadał mu sens w nowej rzeczywistości kulturowej i „ocalił” w muzealnej gablocie? Nie odpowiedź na to pytanie jest tak ważna, jak fakt, że w ogóle się pojawiło, ponieważ samo w sobie jest dobitnym potwierdzeniem teorii Seligmana. Prawo własności - czynnik istotny w naszej przestrzeni kulturowej - może okazać się obcy lub drugorzędny wobec realiów, w których powstał przedmiot. Wtedy widać, jak system etyczny określający moralny imperializm właściwy naszym realiom kulturowym staje się pryzmatem postrzegania odmiennego systemu wartości.

Problem własności kulturowej ukazany sensu stricto na przykładzie muzeum etnograficznego ma swoje dookreślenie i rozwinięcie w rozważaniach o muzeum sztuki. Powodów tego przesunięcia można szukać w dokonanym przez Bal odwróceniu. Proponuje ona zastosowanie kategorii własności kulturowej w stosunku do muzeum sztuki, w którym do tej pory dominowały kryteria estetyczne. Konsekwencją tego jest objęcie kryterium dominacji estetycznej muzeów etnograficznych. Ukazuje również zastosowanie kategorii własności kulturowej w stosunku do wytworów „naszej kultury”, w tym „sztuki”, a nie artefaktów pochodzących z innego obszaru kulturowego, ale eksponowanych według „naszych standardów” i w „naszym muzeum”. Zabieg ten możliwy jest dzięki rezygnacji z estetyki i etyki jako pojęć wartościujących. Zamiast nich warto odwołać się do semiotyki, czyli ogólnej teorii znaków, umożliwiającej interdyscyplinarną analizę za pomocą lingwistycznych narzędzi. 


\section{Muzeum etnograficzne - muzeum sztuki}

Ważne jest zatem „samo rozróżnienie między muzeum etnograficznym, a muzeum sztuki, które jest ideologicznym błędem, ponieważ legitymizuje to, co powinno podlegać krytycznej analizie" (Bal 2005, 353). Ta analiza to właśnie środek eksponujący dyskursywny charakter muzeum i świadczący o świadomości językowej natury obiektów i ich badań. W tym miejscu otwierają się drzwi do interdyscyplinarnych spotkań teorii literatury i muzeologii. Sam dyskurs natomiast „rozumiany jako najwyższa forma organizacji wypowiedzi posiada potencjał analityczny". I tak analiza dyskursu sprowadza się do tropienia pojedynczych, niejednorodnych elementów, połączonych w systemy znaczeń. Owe konstrukcje określają zarówno relacje wewnątrzsystemowe, jak i te pomiędzy poszczególnymi systemami. To twierdzenie, choć oczywiste dla filologów, w przestrzeni analizy muzeum może stanowić novum. W ten sposób lingwistyka, obok antropologii krytycznej, służy rozwijaniu „nowej muzeologii” jako interdyscyplinarnej praktyki badania instytucji muzeum.

Dyskurs - to „retoryczność wpisana w narrację” (Bal 2005, 353), a nie opisy towarzyszące wystawom, teksty zawarte w broszurach czy katalogach. I właśnie z tego punktu widzenia zasadne jest powtórne przywołanie rozróżnienia na muzea etnograficzne i muzea sztuki. Te pierwsze - zajmują się konserwacją i ekspozycją artefaktów, a także ich opisywaniem, gromadzeniem i przechowywaniem. To samo względem dzieł czynią muzea sztuki. Z semiotycznego punktu widzenia definicja obrazu i artefaktu jest podobna. Odmienność polega na istnieniu kulturowej różnicy, oczywistej z punktu widzenia artefaktu i maskowanej, jakby ukrywanej przez dzieło sztuki. Bal ową różnicę wywodzi z definicji dzieła sztuki - postrzeganego jako reprezentacja pewnej estetyki i w konsekwencji traktowanego jako metafora, transponująca swoją „specyficzną estetykę na estetykę określonego kierunku, który pozwoli na odczytanie danego dzieła sztuki jako SZTUKI, niezależnie od tego, co mogłoby nam ono powiedzieć o kulturze, z której się wywodzi" (Bal 2005, 355) oraz z definicji etnicznego artefaktu, który „reprezentuje przede wszystkim szerszy kontekst kultury, z jakiej pochodzi, tym samym nie jest on metaforą, ale synekdochą, zatem artefakt, bez względu na to, jakie wartości estetyczne może posiadać, jest odczytywany tylko jako KULTURA" (Bal 2005, 355).

\section{Filolog w muzeum - metafora, synekdocha, alegoria i metonimia}

W tym miejscu właśnie uwidocznia się wartość kompetencji filologa jako badacza, komentatora, gościa i niejednokrotnie edukatora w muzeum. Warto pamiętać przy tym, że zarówno metafora, jak i synekdocha to pojęcia złożone. Przeszczepienie ich z obszaru teorii literatury na grunt muzeologii nie jest zatem łatwe i zakłada pewne uproszczenie. I tak metafora to dla filologów „wyrażenie, w którego obrębie następuje zamierzona przemiana 
znaczeń składających się na nie słów. Nowe, zmienione znaczenie, zwane metaforycznym, kształtuje się zawsze na fundamencie znaczeń dotychczasowych" (hasło: metafora, Słownik terminów literackich 1988, 274) - tu przede wszystkim na fundamencie podstawowego znaczenia wyrazu i jego znaczeń skonwencjonalizowanych, pod presją nowego kontekstu słownego. Zjawisko to - związane z polisemią ${ }^{2}$ - akcentuje różnorodność samych konstrukcji metaforycznych, od metafory potocznej do poetyckiej i pojęciowej. Jednocześnie funkcja metaforyczna może zaistnieć również w ramach synekdochy - czyli „odmiany metonimii, opartej zwłaszcza na zależnościach ilościowych między zjawiskami, których nazwy zostały użyte jedna zamiast drugiej" (hasło: synekdocha, Słownik terminów literackich 1988, 506). W kontekście muzeologii oznacza to, że dzieło sztuki może - nie rezygnując z funkcji metaforycznej, jednocześnie na zasadzie synekdochy reprezentować część szerszego kontekstu.

Ta sama refleksja - choć odwrócona - dotyczyć może artefaktu, nie tylko jako reprezentacji kultury, z której się on wywodzi, ale przede wszystkim metaforycznie, jako reprezentacji wyborów estetycznych dokonanych przez kuratorów wystawy. I tak na przykład przedmiot pochodzący z cywilizacji pozaeuropejskiej zostaje umieszczony w europejskim muzeum etnograficznym. Na pozór nie dzieje się nic nadzwyczajnego, ale w istocie zaszły tu założone procesy. To w ich zrozumieniu i opisaniu pomagają metafora i synekdocha. Po pierwsze centralna synekdocha: przedmiot został przez badaczy uznany za wytwór reprezentatywny dla danej społeczności w danym okresie - pozbawiono go funkcji jednostkowej - zamiast wyjątkowości zyskał złudną uniwersalność. Jaki jednak był kontekst? Może badacze odnaleźli „n” przedmiotów bardzo do siebie podobnych i na tej podstawie uznali, że ten jest taki, jak one - zatem może je reprezentować. Czy to jednak oznacza, że inne przedmioty, różne od przedmiotów „n”, nie istniały, czy może jeszcze ich nie odnaleziono albo się nie zachowały? To kolejna synekdocha leżąca u podstaw tej pierwszej. Nie kończy ona jednak historii naszego przedmiotu, który jest teraz artefaktem i opisany spoczywa w muzealnym magazynie. To kurator zdecyduje - zgodnie ze swoją wizją ekspozycji - o prezentowaniu tego przedmiotu, który za sprawą procesu metaforyzacji może stać się teraz eksponatem. Oczywiście to jedynie schemat, który można jeszcze dalej rozwijać. Pokazuje jednak praktyczne wykorzystanie teorii lingwistycznej w nowej muzeologii.

Teoria lingwistyczna to nie tylko zastosowanie do analizy muzeum pojęć teoretycznoliterackich. To również narracja - najłatwiej dostrzegalny element języka muzeum. Umożliwia ona takie dysponowanie muzealną przestrzenią, które pozwala poświęcić osobne miejsce każdej z kultur, traktując ją jako synekdochę. Dzięki temu reprezentatywny nie jest już pojedynczy przedmiot, ale dynamiczna relacja zachodząca między kilkoma obiektami ujętymi w zbiór. Badaczka widzi możliwość spiętrzenia tej konstrukcji

${ }^{2}$ Polisemia - zdolność języka pozwalająca na rozszerzenie semantyki poprzez kontekst. 
z poprzednio analizowaną w zjawisku podwójnej synekdochy. Dobrym przykładem jest historia eksponatu pochodzącego z obszaru „a” (nabytego tam, a nie w obszarze „b”), choć spełniającego swoją rolę - jako kontekst kulturowy obszaru „b”. (Bal 2005, 356). Przykład ten wskazuje z jednej strony możliwość mistyfikacji za pomocą narracji, ale z drugiej - jej rolę demaskatorską. To właśnie ona możliwa jest w muzeum w "obszarze x" zdystansowanym naukowo, etycznie, kulturowo od obszarów „a” i „b”. W ten sposób „odczytanie” staje się - również w muzeum - częścią znaczenia, które tworzy. To jedna z kluczowych zmian ujmująca muzeum jako przestrzeń debaty i krytycznej refleksji, a nie „prawdy objawionej”.

Owo „odczytanie” determinowane jest również przez miejsce, rozumiane jako rzeczywista przestrzeń, ściana $\mathrm{w}$ rzeczywistym muzeum. Pozwala to na uruchomienie jeszcze jednej kategorii teoretycznoliterackiej - alegorii. Warto wskazać za Bal przykład recepcji obrazu Gustawa Courbeta Pracownia malarza, zwanego też Rzeczywista alegoria, wprowadzonego w kategorię hiperramy. Co to oznacza? Obraz Courbeta to skomplikowane przedstawienie zarówno $\mathrm{w}$ planie kompozycyjnym, kolorystycznym, jak i symbolicznym. W centralnej części dostrzegamy malującego krajobraz Courbeta z synem i nagą modelką, po lewej stronie grupę postaci, wśród nich kapłana, myśliwego, kobietę karmiącą niemowlę. Po prawej stronie widzimy przedstawicieli wyższych klas społecznych i przyjaciół artysty, a w prawym dolnym rogu czytającego Charles'a Baudelaire'a. Obraz określany jako rodzaj „sceny świata” doczekał się licznych interpretacji. Postrzegano go jako alegorię następujących po sobie faz życia czy odzwierciedlanie poglądów artysty dotyczących natury świata. Dostrzegano zatem w obrazie ramę, rozumianą metaforycznie, jako drugie znaczenie dzieła wymuszone jego alegorycznym statusem. Hiperrama tego statusu nie neguje, ale pozwala na interpretowanie obrazu jako konkretnego obiektu znajdującego się na konkretnej ścianie w Musée d'Orsay w Paryżu. Zatem jak konkluduje badaczka - „cokolwiek obraz oznacza (czy jest to dobre, czy złe) zawsze będzie oznaczał coś innego niż on sam, niż ten obraz na konkretnej ścianie" (Bal 2005, 362). Interpretacja jest tu wynikiem działania alegorycznego, rozumianego jako oderwanie się od rzeczywistości.

Uzupełnienie tak zarysowanego zestawu narzędzi retorycznych widzi Bal w metonimii, uznając związek metonimiczny za „rzeczywistą cechę alegorii" (Bal 2005, 364). Zdaniem badaczki:

metafora pozwala na przekraczanie tego, co widzialne, a więc zachęca do ucieczki od rzeczywistości, (...) synekdocha to, co widzialne wchłania, a zatem prowadzi do imperializmu. (...) Metonimia natomiast, ponieważ jest oparta na związku przyległości ani nie wchłania, ani nie ucieka od rzeczywistości, lecz przywraca przemieszczenie, przypomina o tym, co było (Bal 2005, 365).

$\mathrm{W}$ ten sposób zwiedzanie muzeum może być postrzegane jako akt budowania znaczeń. To właśnie za sprawą metonimii owe znaczenia są 
wynikiem analizy retorycznej i przywrócenia perspektywy narratologicznej. Muzeum to dyskurs, $\mathbf{w}$ ramach którego wystawa stanowi pewną wypowiedź. To właśnie przy analizie tej wypowiedzi warto skorzystać z narzędzi teoretycznoliterackich.

\section{Dyskursy a intertekstualność - o poetyce wielości}

Lingwistyczna teoria Bal inspiruje do stawiania pytań o kontekst przywoływanych przez badaczkę kategorii i refleksje nad ich zasadnością, również w przestrzeni edukacji. W toku krytycznej lektury warto zwrócić uwagę na tworzenie się wielowarstwowej struktury dyskursów. Dotyczy to zarówno muzeum sztuki, jak i muzeum etnograficznego. Polemizować zatem można z tytułem eseju, w którym dyskurs występuje w liczbie pojedynczej. W toku prowadzonej argumentacji wydaje się to niemożliwą iluzją, by ostatecznie zostać jednak ujętym w nową ramę. To w niej muzeologia przygląda się sama sobie. Dzieje się to nie inaczej, jak poprzez dyskurs, który sama wytworzyła. Autorka wskazuje na licznych nadawców komunikatu i kształtujące go konteksty, które - zależnie od nasilenia - same stają się komunikatami. Korzystniejsze zatem, z punktu widzenia muzeum, wydaje się akcentowanie nie dyskursu - jako kategorii analitycznej muzeum, ale dyskursywności - jako jego cechy.

Jednym z przykładów realizacji tego postulatu może być tworzenie wystaw edukacyjnych ${ }^{3}$ demaskujących „język muzeum” i domagających się twórczej analizy, podkreślających rolę narracji: zarówno tej związanej z prezentowanymi przedmiotami, miejscem ekspozycji, obszarem tematycznym, wizją kuratorów - jak i współtworzonej przez widza. Rola wystaw edukacyjnych polega przede wszystkim na kształtowaniu samoświadomości widza, który sam staje się twórcą muzealnej narracji. Taka sytuacja umożliwiła sytuowanie licznych dyskursów w przestrzeni intertekstualnej. I w tym sensie może stanowić rozwinięcie teorii lingwistycznej.

Intertekstualność ${ }^{4}$ nie jest już pojęciem nowym w przestrzeni badań teoretycznoliterackich; nie oznacza to jednak, że istnieje jedna jego przejrzysta definicja. Warto może przypomnieć, że obok bardzo szerokich ujęć tematu, które - jak pisze Ryszard Nycz (Nycz 2000, 81) - podkreślają przede wszystkim pierwszy człon pojęcia, ową relację między tekstami, spotkać można również definicje węższe, waloryzujące tekstualny (tekstowy, a więc literacki) charakter zjawiska. Jak podkreśla jednak autor Tekstowego świata - w kontekście badań interdyscyplinarnych - warto przyjąć tezę, iż „intertekstualność nie jest wyłącznie własnością literatury" (Nycz 2000, 82). Badacz

\footnotetext{
${ }^{3}$ W praktyce taka wystawa to wynik wspólnych działań kuratorów i widzów. W przypadku zrealizowanej w Muzeum Narodowym w Poznaniu w 2013 r. wystawy edukacyjnej „Co ma koronka do wiatraka?” Niderlandy do współpracy przy tworzeniu ekspozycji i materiałów dydaktycznych zaproszono nauczycieli. W rezultacie wystawa uwzględniała różne style uczenia się, odwoływała się do różnych rodzajów inteligencji i percepcji. Ukazując codzienność w siedemnastowiecznych Niderlandach (zatem kontekst odległy kulturowo), silnie eksponowała pytanie o świat współczesny.

${ }_{4}^{4}$ Autorką pojęcia jest Julia Kristeva, posłużyła się ona tym terminem, wywiedzionym z Bachtinowskiej teorii dialogiczności wypowiedzi, w swojej książce wydanej w Paryżu w 1969 r.
} 
wskazuje zasadność stosowania tego terminu również w kontekście plastyki i muzyki. Jak jednak może funkcjonować to pojęcie w przestrzeni muzeologii? Zapewne jest to możliwe dzięki kontekstowi samych muzealiów, czyli obiektów - w przypadku muzeum sztuki o wartości artystycznej. Taką refleksję dotyczącą związków międzyobrazowych podejmuje w swojej pracy Stanisław Czekalski (Czekalski 2006). Tutaj znaczącą rolę odgrywa ekspozycja muzealna, funkcjonowanie obiektów obok siebie w rzeczywistej przestrzeni. Zatem znaczy celowe umiejscowienie obrazów na konkretnej ścianie w specjalnie zaaranżowanym pomieszczeniu, w konkretnej bryle architektonicznej - budynku muzeum. Z drugiej strony ów potencjał intertekstualnej lektury realizuje się właśnie jako bezpośrednia konsekwencja, a zarazem narzędzie teorii lingwistycznej. To tekst - choć trafniej byłoby w tym miejscu zastosować rzeczownik przekaz - sygnalizuje istnienie, świadomie wprowadzonych przez autora nawiązań. Ich znaczenie określane jest przez interpretant. Zgodnie z definicją Riffaterre'a „syntetyzuje on najbliższe kontekstowo semantyczne instrukcje odbioru danego fragmentu [tu: przekazu B.N.], wyznaczając perspektywę jego trafnej lektury" (za: Nycz 2000, 91). To, co wydaje się potencjalnie najbardziej twórczą sferą pojęcia intertekstualność, zawiera się w owym między. Pozwala przekroczyć granicę wskazywania i badania źródeł - hipotekstów i zwraca uwagę na znaczenie gry (Nycz 2000, 108). Celem jej wydaje się negowanie toku lektury systemowej, czyli takiej, która wskazuje opozycje między hipertekstem a hipotekstem (kontekstem). Zastępuje ją lektura polegająca na wskazywaniu nawiązań i związków - jako nośników nowych sensów (Nycz 2000, 109). Taki sposób czytania pozwala rozpatrywać wzajemne zależności. To cenna perspektywa dla nowej muzeologii.

Kwestią pierwszoplanową przy analizie intertekstualnych nawiązań jest wskazanie ich celowości, co w przypadku akcentowania samoświadomości „nowej muzeologii” jako dziedziny metakrytycznej $5 \mathrm{i}$ autorefleksyjnej wydaje się warunkiem sine qua non powyższych rozważań. Ponadto nawet świadomie wprowadzony element może pełnić w nowym kontekście różne role. Warto zatem po raz kolejny za Nyczem wskazać na zjawiska dekontekstualizacji i rekontekstualizacji (Nycz 2000, 103-104) - jako podstawową sferę odniesienia w tym przypadku. Pierwsza oznacza posłużenie się elementem, który został zapożyczony z danego tekstu (źródła), pozbawiony zatem swojego otoczenia, które warunkowało jego sens. Ten element następnie jest poddany rekontekstualizacji, czyli wprowadzeniu w nowy porządek znaczeń. Warto pamiętać, że zachowuje świadomość genealogiczną. Nie każde jednak zapożyczenie możemy uznać za nawiązanie intertekstualne. Nie będzie nim przypadek autorytatywnego postrzegania hipotekstu, wobec którego hipertekst jest całkowicie podporządkowany - zatem zjawisko jednogłosowości. Michał Głowiński proponuje, za Giselle Mathieu-Castellani, stosowanie tu terminu alegacja (za: Nycz 2000, 110). Oznacza to, że istnienie jednego,

5 Czyli samokrytycznej, w której przedrostek meta wskazuje na językowy charakter analizy. 
prymarnego dyskursu muzeum wyklucza dialogiczność, a tym samym uniemożliwia intertekstualne odczytanie. W tym sensie intertekstualność jest konsekwencją i jednocześnie warunkiem koniecznym nowej muzeologii. Przekroczenie jednogłosowości to przekroczenie paradygmatu dawnego postrzegania muzeum.

Pozostaje również problem narracji pierwszoosobowej, monologu, w którym Bal dostrzega upozorowaną rozmowę. Oznacza to symulację postawy otwartości na znaczenia wnoszone do tej pozornej rozmowy przez zwiedzającego. Zaprzecza to recepcyjnej teorii historii sztuki i w gruncie rzeczy edukacyjnej funkcji muzeum. Szczególnie że tę drugą definiujemy współcześnie podmiotowo - jako waloryzującą partnerski, a nie autorytarny, model dydaktyczny. I tu ważki wydaje się potencjał wielu dyskursów opartych na dynamicznej relacji tworzenia znaczeń. Pozwoliłoby to różnicować funkcję edukacyjną szkoły, rozumianą jako elementarna, wychowująca dla sztuki (Kłakówna 1998, 108-121) i muzeum jako przestrzeni niejednorodnej interpretacji.

W ten sposób zamiast o ograniczeniach instytucji warto myśleć o jej możliwościach - również edukacyjnych. Najlepiej w zgodzie z nieobcym dydaktykom postulatem, który Andrea Hauenschild uczyniła mottem swojej pracy poświęconej nowej muzeologii: „At the center of this idea of a museum lie not things, but people” (Hauenschild 1988, 3). A to jest już wartość sama w sobie.

\section{Bibliografia:}

Bal Mieke, 2005, Dyskurs muzeum, 2005, Nitka M. (przeł.) w: Popczyk M. (red.), Muzeum sztuki. Antologia, Kraków,

Czekalski Stanisław, 2006, Intertekstualność i malarstwo. Problemy badań nad związkami międzyobrazowymi, Poznań,

Głowiński Michał, Kostkiewiczowa Teresa, Okopień-Sławińska Aleksandra, Sławiński Janusz (red.), 1988, Słownik terminów literackich, Wrocław,

Hauenschild Andrea, 1988, Claims and Reality of New Museology. Case studies in Canada, the United States and Mexico, New York,

Kłakówna Zofia Agnieszka, 1998, Projektowanie sytuacji odbioru tekstów kultury, w: Kwiatkowska-Ratajczak M. i Wysłouch S. (red.), Konteksty polonistycznej edukacji, Poznań,

Nycz Ryszard, 2000, Tekstowy świat. Poststrukturalizm a wiedza o literaturze, Kraków.

\section{O Autorce:}

Beata Niklewicz - doktorantka w Zakładzie Dydaktyki Literatury i Języka Polskiego na Wydziale Filologii Polskiej i Klasycznej. Historyk sztuki, studentka muzykologii, autorka dwóch książek „Świat z bakelitu”. O poezji Stefana Andrzeja Borsukiewicza (2013) i Między muzycznościa a biologizmem. O kategorii rytmu w twórczości malarskiej Stanisława Ignacego Witkiewicza (2014) oraz wielu artykułów metodycznych. 
